\title{
Genotoxicity effects of Phanerochaete chrysosporium against harmful algal bloom species by comet assay
}

\author{
Guoming Zeng ${ }^{*}$, , Maolan Zhang ${ }^{* 2, b}$ and Pu Wang ${ }^{3, c}$ \\ ${ }^{1}$ Chongqing University of Science and Technology,P. R. China \\ ${ }^{2}$ Sichuan University of Science \& Engineering,P. R. China \\ ${ }^{3}$ Chongqing University, P. R. China \\ azeng373064894@126.com , ${ }^{\mathrm{b}} 511926581 @ 126 . c o m,{ }^{\mathrm{c} w p u 2120 @ 126 . c o m}$
}

\begin{abstract}
Keywords: Water eutrophication, Phanerochaete chrysosporium, Genotoxicity
Abstract. Water eutrophication have become serious ecological problems. White-rot fungi have been demonstrated to be a feasible means of control, but the genotoxicity mechanisms involved have not been reported. In this study, Cryptomonas obovata FACHB-1301 was co-cultured with Phanerochaete chrysosporium under optimal conditions of $250 \mathrm{mg}^{-1}$ at $25^{\circ} \mathrm{C}$ with DO $7.0 \mathrm{mg}^{-1}$ for 1,3 , 5 and $7 \mathrm{~d}$. Compared to the control, the DNA damage in the algal species was greatly decreased after treatment with Phanerochaete chrysosporium by comet assay. The result showed that Phanerochaete chrysosporium could effectively decreased genotoxicity effects .
\end{abstract}

\section{Introduction}

Water eutrophicationhave, characterized by abnormal reproduction of algae and other aquatic organisms in aquatic ecosystems, are one of the most serious environmental problems in lakes, reservoirs and other natural bodies of water $[1,2]$. It not only deteriorate water quality, block aquatic organism physiological development and damage the structure of aquatic ecosystems, which also destroy the function of bodies of water and the ecological environment [3-5].

White-rot fungi could degrade or decrease various environmental pollutants [6,7]. However, the genotoxicity effects of algal species co-cultured with white-rot fungi have not been investigated.The comet assay could be used for the quantitative determination of DNA damage at the single-cell level, and it is suitable for monitoring genetic damage [8].

The aims of the present study was to evaluate the genotoxicity effects of Phanerochaete chrysosporium on Cryptomonas obovata FACHB-1301 using the comet assay .

\section{Materials}

\section{Algal strains and cultivation}

Cryptomonas obovata FACHB-1301 was provided by the Freshwater Algae Culture Collection of the Chinese Academy of Sciences, and maintained in an illuminated incubator for $15 \mathrm{~d}$ at $25{ }^{\circ} \mathrm{C}$ on a $12 \mathrm{~h} / 12 \mathrm{~h}$ light/dark cycle with approximately $90 \mu \mathrm{mol}$ photons $\mathrm{m}^{-2} \mathrm{~s}^{-1}$ provided by cool-white fluorescent lamps to achieve exponential growth.

The growth medium for Cryptomonas obovata (FACHB-1301) was AF-6 [140 mg NaNO $3,10 \mathrm{mg}$ $\mathrm{KH}_{2} \mathrm{PO}_{4}, 5 \mathrm{mg} \mathrm{K} \mathrm{HPO}_{4}, 22 \mathrm{mg} \mathrm{NH} \mathrm{NO}_{3}, 10 \mathrm{mg} \mathrm{CaCl} \cdot 2 \mathrm{H}_{2} \mathrm{O}, 2 \mathrm{mg}$ Fe-citrate, $30 \mathrm{mg} \mathrm{MgSO} \mathrm{Mg}_{4} \cdot 7 \mathrm{H}_{2} \mathrm{O}, 2$ mg citric acid, $2 \mu \mathrm{g}$ Biotin, $10 \mu \mathrm{g}$ Thiamine $\mathrm{HCl}, 1 \mu \mathrm{g}$ Vitamin $\mathrm{B}_{6}, 1 \mu \mathrm{g}$ Vitamin $\mathrm{B}_{12}, 0.4 \mathrm{~g}$ MES, $6 \mathrm{ml}$ trace metal solution (PIV), and $994 \mathrm{ml}$ distilled water ( $\mathrm{pH} \mathrm{6.6)].} \mathrm{The} \mathrm{PIV} \mathrm{solution} \mathrm{comprised} 41 \mathrm{mg}$ $\mathrm{MnCl}_{2} \cdot 4 \mathrm{H}_{2} \mathrm{O}, 750 \mathrm{mg} \mathrm{Na} 2 \mathrm{EDTA}, 97 \mathrm{mg} \mathrm{FeCl} \cdot 6 \mathrm{H}_{2} \mathrm{O}, 5 \mathrm{mg} \mathrm{ZnCl} \cdot 7 \mathrm{H}_{2} \mathrm{O}, 4 \mathrm{mg} \mathrm{Na} \mathrm{MoO}_{4} \cdot 2 \mathrm{H}_{2} \mathrm{O}$, and 2 $\mathrm{mg} \mathrm{CoCl} \cdot 6 \mathrm{H}_{2} \mathrm{O}$, in $1000 \mathrm{ml}$ distilled water.

\section{Fungal strains}

Phanerochaete chrysosporium was provided by the Center of Industrial Culture Collection, China. Controls throughout the experiments were the same cultures as the test groups but without Phanerochaete chrysosporium. 


\section{Animal experimental design}

Fejervarya multistriat tadpoles were collected from the Chongqing farmland suburbs and placed in a no-pollution eco-pond $\left(27-28{ }^{\circ} \mathrm{C}\right)$. Healthy tadpoles with uniform size were selected at stage 32-36, and their body length and weight were $26.28 \pm 0.34 \mathrm{~mm}$ and $0.19 \pm 0.019 \mathrm{~g}$, respectively.

Fejervarya multistriat tadpoles were fed the algae and the algae treated with Phanerochaete chrysosporium under optimal conditions for Phanerochaete chrysosporium $250 \mathrm{mg}-1$ at DO $7.0 \mathrm{mg}-1$ with $25{ }^{\circ} \mathrm{C}$ and $12: 12 \mathrm{~h}$ (light:dark) cycle for $1,3,5$ and $7 \mathrm{~d}$, respectively. The concentration of chlorophyll-a was $163 \mathrm{mgL}^{-1}$,respectively.Controls throughout the experiments were the same cultures as the test groups but without Phanerochaete chrysosporium.

\section{Analytical methods}

\section{Comet assay}

The alkaline version of the comet assay was performed according to guidelines proposed by Singh[9].

\section{Results and Discussion}

Table 1. DNA damage induced by Cryptomonas obovata FACHB-1301, and co-cultured with Phanerochaete chrysosporium on blood cells as detected by Comet assay.

\begin{tabular}{|c|c|c|c|c|}
\hline \multirow{2}{*}{$\begin{array}{c}\text { Time (d) } \\
0\end{array}$} & \multicolumn{2}{|c|}{ Tail length } & \multicolumn{2}{|c|}{ Comet length } \\
\hline & $0.45 \pm 0.09 a$ & $0.45 \pm 0.09 b$ & $1.12 \pm 0.21 a$ & $1.12 \pm 0.21 b$ \\
\hline 1 & $10.56 \pm 0.45 a$ & $4.34 \pm 0.52 * b$ & $31.35 \pm 0.32 a$ & $13.42 \pm 0.57 * b$ \\
\hline 3 & $31.68 \pm 0.34 a$ & $19.68 \pm 0.46 * b$ & $55.36 \pm 0.86 a$ & $25.57 \pm 0.82 * * b$ \\
\hline 5 & $41.53 \pm 0.57 \mathrm{a}$ & $28.51 \pm 0.75 b$ & $69.17 \pm 0.73 a$ & $39.86 \pm 0.91 * * b$ \\
\hline 7 & $61.44 \pm 0.43 a$ & $36.77 \pm 0.54 * * b$ & $91.45 \pm 0.65 a$ & $55.67 \pm 0.68$ b \\
\hline
\end{tabular}

a Cryptomonas obovata FACHB-1301, b Cryptomonas obovata FACHB-1301 co-cultured by Phanerochaete chrysosporium.Compared with control group; $* \mathrm{P}<0.05$; **P $<0.01$.

As can be seen from the table 1, the control groups all showed migration, and the tail lengths was increased from $0.45 \pm 0.09$ to $61.44 \pm 0.43$ in control group-treated tadpoles after $7 \mathrm{~d}$. Compared to the control groups, the migration of DNA from tadpoles exposed to algae treated with Phanerochaete chrysosporium was only increased to $36.77 \pm 0.54$. The comet length of the control groups ranged from $1.12 \pm 0.21$ to $91.45 \pm 0.65$ with the $7 \mathrm{~d}$ treatment, but these values reached $55.67 \pm 0.68$ in the experimental groups after $7 \mathrm{~d}$. These results indicated that the red blood cells of Fejervarya multistriat tadpoles could be seriously affected by algae in water where the algae underwent eutrophic growth or rupture. After treatment with Phanerochaete chrysosporium, the comet rate and degree of DNA damage were less than the control.

\section{Conclusion}

In this study, Cryptomonas obovata FACHB-1301 treated by Phanerochaete chrysosporim, showed lower genotoxicity effects in tadpoles than in tadpoles that were directly exposed to algae. We also found that DNA damage in the red blood cells of Fejervarya multistriat tadpoles was significantly induced by the algae but was lower after the algae treated by Phanerochaete chrysosporium.

\section{Acknowledgements}

This work was financially supported by the National key research and development program (2017YFC0404706-1); the Department of Science and Technology of Sichuan Province (2017JY0129); the Education Committee of Sichuan Province (17ZB0299,17ZB0313,17ZB031 2); the Three Gorges reservoir area ecological environment Ministry of education key laboratory open fund (2016ZJSX-003,2016ZJSX-001);the Sichuan University of Science and Technology level talent introduction project(2014RC32, 2016RCL20,2016RCL06); the Sichuan province students innovation and entrepreneur- ship training plan(201610622036). 


\section{References}

[1] R.Q. Su, X.R. Yang, T.L. Zheng, Y. Tian, N.Z. Jiao, L.Z. Cai,and H.S. Hong:Harmful Algae Vol.799-810 (2007),p.6.

[2] G. Campbell, S.R. Phinn, A.G. Dekker, and V.E. Brando, Remote. Sens. Environ Vol.2402-2414l(2011), p.115.

[3] A.Zamyadi, S.L.Mac Leod, Y.Fan, N.Mc Quaid, S.Domer, S.Sauve, and M.Prevost, Water. Res Vol. 1511- 1523 .(2012), p.46.

[4] W.S.Zong ,F.Sun and X.J.Sun, Water. Res Vol.3211-3219 (2013),p.47.

[6] F.F.Ma, F.Carbone, G.C.Forti, A.Buschini, P.Poli, C.Rossi, L.Marabini, S.Radice, E.Chiesara , and P.Hrelia, Environ. Int Vol.1053-1061(2009),p.35.

[7] S.K.Ai, and C.D.Metcalfe, Mutat.Res Vol. 121-135(1995),p.343.

[8] K. Crasta, N.J. Ganem, R. Dagher, A.B. Lantermann, E.V. Ivanova, Y. Pan, L. Nezi,A.

Protopopov, D. Chowdhury, and D. Pellman, Nature Vol.53-58 (2012),p.482.

[9] N.P.Singh, M.T. McCoy, R.R.Tice and E.L.Schneider, Exp. Cell Res Vol.184-191 (1988),p.175. 